\title{
MÓWIENIE - ROZMOWA - DIALOG - DYSKUSJA
}

\begin{abstract}
Streszczenie. Mówienie, rozmowa, dialog i dyskusja to cztery bliskoznaczne terminy i cztery fenomeny ze sobą spokrewnione. Mówienie to sensowne artykułowanie dźwięków przez podmiot osobowy i jako takie jest warunkiem pozostałych aktywności. Rozmowa jest wzajemnym mówieniem do siebie przynajmniej dwóch osób na jakiś temat. Dialog i dyskusja, będące rozmową osób, różnią się przedmiotem, celem i strukturą. Dla obu rozmowa jest fundamentem. Warunkiem dialogu i dyskusji jest wewnętrzna wolność osób, które w nich biorą udział. Głównym celem dialogu jest zapoznanie się ze stanowiskiem i poglądami jego uczestników na określony temat. Uczestnicy dialogu nie muszą posiadać równych kompetencji. Dyskusja jest dialogiem sformalizowanym, kwalifikowanym. Jej celem jest rozwiązanie jakiegoś problemu. W dyskusji musi być zatem wyraźnie określony jej przedmiot, aspekt oraz muszą zostać uzgodnione pojęcia. Dyskutanci muszą posiadać podobne kompetencje w dyskutowanych sprawach. Dyskusja posiada też swą wewnętrzną, logiczną strukturę.
\end{abstract}

Słowa kluczowe: mówienie; rozmowa; dialog; dyskusja

1. Wprowadzenie. 2. Mówienie. 3. Rozmowa. 4. Dialog. 5. Dyskusja. 6. Podsumowanie.

\section{WPROWADZENIE}

„Mówienie”, „rozmowa”, „dialog”, „dyskusja” - to cztery bliskoznaczne terminy, które w języku codziennej komunikacji używane są zamiennie ${ }^{1}$. Ich bliskoznaczność potwierdzają słowniki. I tak np. Stownik jezyka polskiego Mieczysława Szymczaka podaje, że „mówienie” wywodzi się od czasownika „mówić”, który znaczy tyle, co „posługiwać się słowami dla komunikowania myśli i przeżyć; mieć zdolność mowy; (...) informować, podawać do wiadomości; głosić, opiewać; (...) wyrażać coś, coś znaczyć, świadczyć o czymś”. „Roz-

1 Artykuł niniejszy poszerza problem podjęty przeze mnie w: Dialog i dyskusja, Zarządzanie i Edukacja (2010)68-69, 235-244 i precyzuje niektóre tezy tam zawarte. 
mowa” to - pierwszorzędnie - „wzajemna wymiana myśli za pomocą słów; mówienie z kimś, rozmawianie, konwersacja, pogawędka”. „Dialog” jest natomiast określany jako „rozmowa, zwłaszcza dwóch osób”, a „dyskusja” - jako „ustna lub pisemna wymiana zdań na jakiś temat (zwykle publiczna), wspólne omawianie, rozpatrywanie jakiegoś zagadnienia; rozmowa, dysputa" 2 . Zasadniczo takie same znaczenia wszystkich czterech wyrazów podaje internetowy Stownik jezyka polskiego PWN, dodając jedynie do znaczenia wyrazu „dialog”, że jest to „rozmowa dwóch osób, zwłaszcza bohaterów powieści, sztuki lub filmu"3. Jeszcze bardziej bliskość znaczeń i zastępowalność tych wyrazów w mowie potocznej uwidacznia się, gdy przypatrzymy się ich frazeologii. Nie wydaje się jednak, aby można było zasadnie utrzymywać, że znaczenia tych wyrazów się pokrywają, a jeszcze bardziej, że tym samym jest mówienie, rozmowa, dialog i dyskusja. Twierdzę raczej, że w istocie są to różne, a przynajmniej różniące się fenomeny, bliskie sobie, które wymagają istotnościowego uchwycenia i eksplikacji. Już tutaj zauważyć należy, że choć wszystkie nazwy, wskazujące na interesujące nas tu fenomeny, są rzeczownikami, wywodzącymi się od czasowników: „mówić”, „rozmawiać”, „dialogować”, „dyskutować”, nie zawsze jednoznacznie wskazują na odpowiednią czynność mówienia, rozmawiania, dialogowania czy dyskutowania. „Rozmowa”, „dialog” czy „dyskusja” wskazują raczej na rezultat owych czynności, gdy rezultatem czynności mówienia jest mowa. W codziennym, potocznym i naukowym użyciu tych słów zasygnalizowane tu różnice rzadko są dostrzegane, a zwyczaj językowy, dotyczący polskiego, niektóre z tych form wyróżnia, a inne „usuwa w cień”, choć nie eliminuje. Analiza frazeologiczna przywołanych tu słów wskazałaby, że i ich powiązania $z$ innymi słowami nie są jednolite.

2 Słownik języka polskiego, red. M. Szymczak, t. 1, PWN, Warszawa 1978, 394, 489; t. 3, 102.

3 https://sjp.pwn.pl, [dostęp 12.9.2020]. 
By nie rozwodzić się nad problemami językowymi, w dalszych rozważaniach wymienione w tytule terminy traktuję pierwszorzędnie jako nazwy czynności, a drugorzędnie - jako nazwy wytworów tych czynności. Analizując ejdetycznie owe fenomeny, będę wydobywał to, co konieczne i wystarczające dla danego fenomenu, zdając sobie sprawę, że najprawdopodobniej (bo na początku badań może to być tylko hipoteza) tworzą one swoiste drzewo Porfiriusza, treściowo zawierając się według następującego porządku: dyskusja zawiera się $\mathrm{w}$ dialogu, ten $\mathrm{w}$ rozmowie, a rozmowa w mówieniu.

\section{MÓWIENIE}

Mowa od zawsze towarzyszy człowiekowi w jego bytowaniu, a ściślej: od zawsze człowiek, będąc człowiekiem, mówi i roz-mawia homo loquens. Nie wnikając, czy posiadanie języka przysługuje tylko człowiekowi, czy też można mówić (niemetaforycznie) o języku np. zwierzą ${ }^{4}$, mówienie ${ }^{5}$ i roz-mowa nie są tożsame z posiadaniem języka jako narzędzia wyrażania myśli i ich komunikacji, języka jako skodyfikowanego systemu znaków konwencjonalnych wraz z ich składnią, pełniących rozmaite funkcje ${ }^{6}$. Niewątpliwie samo mówienie, a cóż dopiero roz-mowa, domagają się języka przede wszystkim jako narzędzia wyrażania myśli, czy może raczej - jako narzędzia kodowania treści myślanych i udostępniania ich drugim? ${ }^{7}$.

4 Zagadnienie języka jako różnicy gatunkowej podjął A. Żychliński, Homo loquens. O różnicy antropologicznej, Teksty Drugie (2009)5, 56-84. Por. także: A. Grzegorczyk, O języku ludzkim jako istotnej cesze człowieka, w: Swoistość człowieka? Język, red. J. Tomczyk, G. Bugajak, Wydawnictwo UKSW, Warszawa 2008, 47-66.

5 Badania antropologii biologicznej wskazują na istotne uwarunkowania anatomiczne, właściwe człowiekowi, umożliwiające mowę artykułowaną. Por. J. Tomczyk, W poszukiwaniu korzeni mowy artykułowanej, w: Swoistość człowieka? Język, dz. cyt., 67-93.

6 Wśród najważniejszych funkcji języka wymienia się funkcje: przedstawiania, powiadamiania, wyrażania, oddziaływania, kontaktowania, kodowania.

7 Szeroko i dogłębnie problem relacji między myślą a językiem przedstawia A. Gut, O relacji między myślą a językiem, TN KUL, Lublin 2009. 
Jednakże pierwszorzędnie mówienie domaga się szczególnej zdolności artykułowania dźwięków, którą - niekiedy - nazywamy mową, jak w zdaniu: „człowiek ma zdolność mowy”. Nie sposób zagłębiać się tu w rozbudowaną teorię języka, ukazującą jego genezę, złożoność i rozmaite jego funkcje. Nie można też nie dostrzec istotowego związku języka, mowy i mówienia z umysłem, co tak wyraźnie widać w bogactwie semantycznym greckiego „logosu”. Odróżnić jednak trzeba samą tkwiącą w człowieku możność mówienia od samego mówienia, będącego tej możności urzeczywistnieniem, czyli od aktów mowy, które domagają się języka jako konwencjonalnego systemu w sensie langue Ferdinanda de Saussure'a, by mogły być indywidualną realizacją tego systemu jako konkretna wypowiedź w sensie parole. Warto też zdać sobie sprawę z trudności w określeniu czy zdefiniowaniu mowy, czego przykład znajdujemy w $O$ nauczycielu Augustyna. Rozmawiając z Adeodatusem łatwiej było im określić wieloraki cel mowy, niż odpowiedzieć na pytanie, co to jest mowa. Nie zadowoliło ich stwierdzenie, że „mowa polega (...) na wypowiadaniu słów”, ani że mówić to „uzewnętrzniać treść swej woli za pomocą artykułowanych dźwięków" ", co nie przeszkodziło im podjąć szczegółowszych tematów, dotyczących języka i jego charakteru znakowego, a przede wszystkim roli nauczyciela w edukacji ${ }^{9}$. I nic dziwnego. Jak w dialogach Platona, tak i w dialogach Augustyna, przedmiotem rozważań są zazwyczaj nieredukowalne do czegoś innego prafenomeny, które wymykają się słownym określeniom, natomiast domagają się rozświetlenia.

8 Augustyn, O nauczycielu, tłum. z łac. J. Modrzejewski, w: Tenże, Dialogi filozoficzne, Wydawnictwo Znak, Kraków 1999, 433-434 (I.1.2).

9 Na podobne trudności w swych badaniach nad językiem i mówieniem natrafił wspomniany już F. de Saussure, Kurs językoznawstwa ogólnego, tłum. z fr. K. Kasprzyk, PWN, Warszawa 19912, 35-47. Wydaje się, że dla niego mowa jest określoną zdolnością, która urzeczywistnia się w językowym mówieniu (parole), czyli w mówieniu określonym językiem (langue). 
Fundamentalnym fenomenem dla naszych rozważań jest mówienie, przejaw określonego habitualnego uposażenia podmiotu mówiącego. Podmiot mówiący, a więc posiadający zdolność mówienia, musi być osobą, co wynika $z$ istoty mówienia. Mówienie bowiem nie jest koniecznością, lecz działaniem dobrowolnym. Jest też działaniem rozumnym, gdyż mówienie zawsze jest mówieniem określonej treści, ukształtowanej przez podmiot. Już na tym poziomie trzeba odróżnić mówienie od dźwięków, wydawanych bezwolnie z różnych racji przez istoty żyjące, jak krzyk z bólu czy z przerażenia, będący raczej oznaką czy symptomem określonego stanu rzeczy, w przeciwieństwie do znaków, które niosą w sobie określoną intencjonalną treść.

Co jest celem mówienia? Wystarczającym celem mówienia jest samo mówienie, mówienie dla mówienia, wcale nierzadkie w życiu ludzi, choć najczęściej dookreślane przez inne cele, dla których mówienie jest środkiem ich urzeczywistnienia. Rezultatem mówienia jest mowa, zawierająca określone treści. Rozumność mówienia określonej treści nie ogranicza jej do treści poznawczych, lecz wskazuje, że nawet mówione czy wypowiadane treści emocjonalne lub wolicjonalne są w mówieniu kształtowane przez intelekt. Ta czysto intencjonalna treść - nawet w tzw. cichym mówieniu - domaga się wyrażenia w języku, przez co staje się - przynajmniej potencjalnie intersubiektywnie dostępna, nie ma bowiem języka niezbywalnie prywatnego. Inaczej niż myślenie, które nawet jeśli jest wyraźnym myśleniem czegoś czy myśleniem o czymś, a nie jedynie umysłowym „czuwaniem”, i jako takie nie domaga się wyraźnego uformowania myślanej treści, mówienie (parole) jest zawsze mówieniem czegoś w jakimś artykułowanym języku, tzn. domaga się ze swej istoty doboru określonych słów i ich powiązania według zasad danego języka (langue). Myśli, a ściślej: treści myślane, które są płynne i mniej lub bardziej rozmyte, gdy są wypowiadane, dzięki językowi zostają uformowane, skonceptualizowane, zyskują względną trwałość i intersubiektywność. Mówienie sformalizowane, a co za tym idzie i jego wytwór, mowa, różnią się tematem, celem, stylem oraz adresatem. 
Arystoteles, którego Retoryka zaważyła na teorii i praktyce retorycznej po czasy współczesne ${ }^{10}$, wyróżnił w swych dziełach mowy codzienne i uroczyste, doradcze (polityczne), sądowe i popisowe, epickie, etyczne i pochwalne, co przywołuję tu gwoli przykładu, by zasygnalizować bogactwo rodzajów mówienia i mów jako jego rezultatów.

Miedzy myśleniem określonych treści a ich mówieniem nie zachodzi związek przyczynowo-skutkowy, lecz motywacyjny. Myślenie motywuje mówienie, lecz go nie determinuje. To, co pomyślane, zawsze transcenduje to, co powiedziane, wykracza poza wypowiedziane treści, które jedynie do pewnego stopnia, nieadekwatnie, wyrażają treści myślane, choć jasność myśli jest warunkiem sine qua non jasności wypowiedzi. Dlatego pragnienie Juliusza Słowackiego, by ,język giętki powiedział wszystko, co pomyśli głowa”, nieobce nie tylko pisarzom, lecz i każdemu człowiekowi, bo każdy choć raz doświadczył nieadekwatności wypowiedzi w stosunku do własnej myśli, nie może być spełnione w pełni. Z kolei - jak powie Arystoteles - „mowa nie spełnia swego zadania, jeśli jasno nie przedstawia myśli"11.

Mówienie czegoś nie musi być mówieniem do kogoś lub do czegoś. Podmiot mówiący nie musi intencjonalnie kierować swej wypowiedzi do kogokolwiek lub czegokolwiek, może po prostu wy-mówić określone treści niejako „W przestrzeń”, może się po prostu wy-powiedzieć, a nawet wy-krzyczeć. Mówienie takie jest wtedy mówieniem określonego podmiotu bez skierowania do kogokolwiek, nawet do siebie samego. Ale można także mówić do kogoś lub do czegoś, nie oczekując żadnej wypowiedzi zwrotnej. Mówienie nie wymaga zatem interlokutora. Może być mono-logiem, czyli autonomiczną

10 Por. M. Korolko, Sztuka retoryki. Przewodnik encyklopedyczny, Wiedza Powszechna, Warszawa 1990, 47.

11 Arystoteles, Retoryka 1404 b 2-3, tłum. z gr. H. Podbielski, w: Tenże, Dzieła wszystkie, t. 6, Wydawnictwo Naukowe PWN, Warszawa 2001, 432. 
mową jednego podmiotu, a nie dia-logiem - o którym przyjdzie nam jeszcze mówić.

Inspirująco w tym miejscu brzmi stwierdzenie Emile'a Beneviste'a, że „każdy mówi od siebie. Dla każdego mówiącego mowa wypływa $\mathrm{z}$ niego i do niego wraca, każdy określa się jako podmiot wobec innego człowieka i innych ludzi. Tymczasem, a być może dlatego język, który w ten sposób jest niemożliwą do zastąpienia emanacją najgłębszego ja każdej jednostki, jest zarazem rzeczywistością ponadindywidualną i rozciąga się na całą zbiorowość. Ta właśnie zbieżność między językiem jako rzeczywistością możliwą do zobiektywizowania i ponadindywidualną oraz indywidualnym wytwarzaniem mowy określa paradoksalną sytuację języka wobec społeczeństwa. Język dostarcza bowiem mówiącemu podstawowej struktury formalnej, pozwalającej na praktykę mówienia. Daje mu narzędzie językowe zapowiadające podwójne funkcjonowanie - subiektywne i referencjalne - wypowiedzi (...)"12.

\section{ROZMOWA}

Inaczej jest z rozmową. Już dopełnienie „mowy” przedrostkiem „roz” wskazuje, że pojęcie „rozmowy” wzbogaca treść pojęcia „mowa”, a zatem i pojęcia „mówienie”, o nowe elementy, przez co roz-mowa ujawnia się jako mowa specyficzna. Jak wskazują to językoznawcy, przedrostek „roz” w wyrazie „rozmowa” funkcjonuje w osobliwy sposób, nietypowy dla tego przedrostka w języku współczesnym. Idąc za sugestiami Krystyny Kleszczowej, wydaje się, że przedrostek ten do czasownika „mówić”, a zatem i do rzeczownika „mowa”, wnosi informację o co najmniej dwóch podmiotach tak nazwanej czynności

12 E. Benveniste, Struktura języka i struktura społeczeństwa, tłum. z fr. K. Falicka, w: Język i społeczeństwo, red. M. Głowiński, Czytelnik, Warszawa 1980, 36. 
oraz o tym, że czynność ta dotyczy czegoś, ma swój temat ${ }^{13}$, co znaczeniowo pokrywa się z łacińskim colloquium.

Roz-mowa jest zatem mówieniem czegoś, lecz zawsze do kogoś. Ze swej istoty domaga się interlokutora, który nie tylko będzie słuchaczem czyjegoś mówienia, jego adresatem, lecz także podmiotem, reagującym własnym mówieniem na czyjąś wypowiedź, mówieniem skierowanym do inicjatora rozmowy. Z natury rozmowy wynika, że domaga się ona zarówno inicjatora rozmowy jak i jego interlokutora, zdolnych nie tylko do mówienia, lecz i do słuchania oraz do rozumienia treści wypowiedzi choćby w minimalnym stopniu. Rozmowa musi zatem dokonywać się w znanym interlokutorom języku, pod którym to terminem trzeba dostrzegać także dialekt, narzecze, żargon czy slang. Wszelka rozmowa jest co najmniej dwupodmiotowa, ale może w niej uczestniczyć większa, choć zawsze mocno ograniczona liczba osób. Wynika to z istoty rozmowy oraz percepcyjnych zdolności jej uczestników. Rozmowa jest zatem interakcją w ramach ograniczonej liczby rozmówców, co wymaga przyjęcia przez nich odpowiedniej postawy i nastawienia. Szczególnym przypadkiem rozmowy jest rozmowa z samym sobą (soliloquium). Umożliwia to dokonujące się $\mathrm{w}$ rozmowie $\mathrm{z}$ sobą samym fenomenalne rozczepienie podmiotu, będącego jednością, na dwa podmioty różnych aktów mówienia, na co w innym kontekście zwrócił uwagę Edmund Husserl14.

Aby rozmowa mogła zaistnieć, musi dojść do spotkania interlokutorów, przy czym wystarczy, by jeden z nich napotkał drugiego, a nawet - natknął się na niego, co oddają zwroty: „spotkanie przypadkowe”, „niezamierzone”, „przelotne”. Potrzeba też, by nie tylko

13 Por. K. Kleszczowa, O wyrazie „rozmowa” słów kilka, w: Porozmawiajmy o rozmowie. Lingwistyczne aspekty dialogu, red. M. Kita, J. Grzenia, Wydawnictwo Uniwersytetu Śląskiego, Katowice 2003, 11-15.

14 Mam tu na uwadze tzw. fenomenalne rozszczepienie czy rozdwojenia się „ja” (Ich-Spaltung), jakie zachodzi między przeżyciem reflektowanym i reflektującym. Por. E. Husserl, Idee czystej fenomenologii i fenomenologicznej filozofii. Księga druga, tłum. z niem. D. Gierulanka, PWN, Warszawa 1974, 143-147. 
zaczęli oni do siebie mówić, lecz by owo mówienie przerodziło się w wymianę myśli, by mimo dwu- lub wielopodmiotowości owego mówienia stało się ono swego rodzaju jednością. Decydujący jest tu temat (przedmiot) i cel rozmowy, które nie tylko nie muszą, lecz zazwyczaj nie są przez rozmówców wyraźnie określone. Często temat rozmowy jest zmienny, co sprawia, że rozmowa jest wielowątkowa. Nie musi prowadzić do żadnych konkluzji i jeśli jest rozmową niekwalifikowaną, do niczego nie zobowiązuje. Przykładem takiej niekonluzywnej rozmowy jest kłótnia, czyli gwałtowna i emocjonalna wymiana zdań osób, niezgadzających się w jakiejś sprawie, w której każda ze stron chce wygrać i pozostać przy swojej racji, przy czym za wygraną w kłótni kryje się cel praktyczny ${ }^{15}$. Podobnie jak się ma sprawa $\mathrm{z}$ mówieniem, celem rozmowy może być ona sama, rozmawiamy żeby po-roz-mawiać - i nic więcej. Niemniej jako taka właśnie jest fundamentem zarówno dialogu, jak i dyskusji, które są kwalifikowaną formą rozmowy.

Jeżeli jednak rozmowa $\mathrm{z}$ woli rozmówców nabiera dodatkowych kwalifikacji, jeśli wykracza poza zdawkową wymianę zdań i myśli, a staje się narzędziem osiągnięcia określonych celów, podejmujący rozmowę muszą przyjąć - choć zazwyczaj spontanicznie - określoną postawę, określone nastawienie, które nadaje rozmowie określony kształt. Od nastawienia interlokutorów zależy typ i jakość rozmowy. Trudno byłoby podać wyczerpującą listę typów rozmowy ze względu na ich rozmaitość. Tytułem przykładu można wymienić rozmowę o rzeczach i rozmowę o poglądach, rozmowę dotyczącą poznania i rozmowę dotyczącą działania oraz wytwarzania, rozmowę wychowawczą i rozmowę edukacyjną, rozmowę w cztery oczy i w szerokim gronie, rozmowę prywatną i rozmowę służbową, rozmowę dyplomatyczną, rozmowę dotyczącą teraźniejszości, przeszłości i przyszłości,

15 Por. Słownik języka polskiego PWN, https://sjp.pwn.pl/szukaj/kłótnia.html, [dostęp 12.9.2020]; Wielki słownik języka polskiego, https://wsjp.pl/index.php?id_hasla=35701, [dostęp 12.9.2020]. 
rozmowę sprawozdawczą i projektującą, rozmowę potoczną i rozmowę ekspercką, wreszcie całą gamę rozmów, dotyczących niezliczonych i różnorodnych spraw i przedmiotów naszego zainteresowania. Podobnie wielorakie jest zróżnicowanie rozmów, gdy idzie o ich jakość. Są rozmowy miłe i niemiłe, banalne i interesujące, zdawkowe i zasadnicze, nudne i ożywione itp. Zdanie sobie sprawy z tej różnorodności rozmów, które nie są prostym mówieniem czegoś lub mówieniem czegoś do kogoś, ma istotne znaczenie dla naszych dalszych rozważań, dotyczących istoty dialogu oraz dyskusji, które są rozmowami szczególnego rodzaju.

\section{DIALOG}

W przeciwieństwie do „mówienia”, „rozmowy”, a także „dyskusji”, słowo „dialog” w świecie współczesnym należy do słów bardzo często używanych, nobilitowanych, a dialog w różnych konfiguracjach jest pożądany niemalże we wszystkich obszarach życia społecznego. Czymże zatem on jest? Jak go rozumieć? Jaka jest jego istota?

Słowo „dialog” wywodzi się od greckiego rzeczownika diálogos, a ten od czasownika dialégein, który przyjmuje następujące znaczenia: wybierać, rozdzielać, wydrążać, wydłubywać, rozmawiać z kimś, dyskutować, wykładać (mieć prelekcję), pisać prozą. Czasownik ten jest zbudowany z przedrostka diá- (przez, za sprawą, dzięki) oraz rdzenia (czasownika) légein, m.in. wskazującego na czynność mówienia ${ }^{16}$. A zatem zgodnie $z$ etymologią dialog jest określonym działaniem, dokonującym się dzięki mówieniu czy za pomocą mówienia, którego celem jest po-rozumienie, czyli dokonane poprzez rozum (diá lógou) wzajemne zrozumienie. Już w tym miejscu uwidacznia się, że nie każda rozmowa jest dialogiem, choć dialog jest rozmową, tylko że kwalifikowaną. Ale czy tylko rozmową?

16 Słownik grecko-polski, red. Z. Abramowiczówna, PWN, Warszawa 1958, t. 1, 536; t. 3, 18. 
Łacińskim odpowiednikiem diálogos jest rzeczownik communicatio, którego treść dopełnia nasze rozumienie dialogu. Rzeczownik ten, wywodzący się od czasownika communicare, znaczy bowiem tyle, co dzielenie się czymś z kimś, dopuszczenie kogoś do udziału w czymś, udzielanie komuś czegoś, wzajemna wymiana czegos ${ }^{17}$ - co dokonuje się w dialogu, jeśli ten jest dialogiem rzeczywistym.

Jako swoiste działanie dialog domaga się określonego podmiotu działającego, a ściślej - co najmniej dwóch podmiotów, które są zdolne takie działanie spełnić. Tymi podmiotami mogą być tylko byty, wyposażone w zdolność mówienia i słuchania, czyli osoby, zdolne do prowadzenia rozmowy. Dialog w swym źródłowym sensie jest bowiem mówieniem osoby do osoby, rozmową między co najmniej dwoma osobami, którego celem jest wzajemne zrozumienie, choć niekoniecznie - porozumienie. Na pewno jednak dialog wyklucza kłótnię, gdyż w niej o zrozumienie drugiej strony nigdy nie chodzi.

Warunkiem koniecznym, lecz niewystarczającym, dialogu jest zatem zdolność mówienia i słuchania u osób dialogujących, czyli nie tyle uczestniczących w dialogu, co go konstytuujących. Dialog nie jest bowiem czymś, w co można „wejść” jako do czegoś wobec mnie obcego, lecz poprzez właściwe dialogowi działanie się go po prostu tworzy. Osobę dialogującą musi cechować otwartość na pozostałych uczestników dialogu i ich stanowiska w określonej sprawie. Od strony ontycznej warunek ten zabezpiecza intelekt, który jest zdolny przyjmować treści, płynące od drugiej osoby, oraz ujawniać własne myśli i emocje. Dzięki temu człowiek może, jeśli chce, przekazać drugiemu człowiekowi wszystko, co jest jego własne i co jest przekazywalne. Ponieważ może to uczynić jedynie, jeśli tego chce, dialog domaga się wolności osób, biorących w nim udział. Intelektualność i wolność, znamionujące osobę i powodujące jej otwartość, są zatem

17 Słownik łacińsko-polski, t. 1, red. M. Plezia, PWN, Warszawa 1959, 611. 
fundamentem wszelkiego dialogu $\mathrm{u}^{18} \mathrm{i}$ nadają mu wymiar moralny. Każdy bowiem dialog, będąc sprawą intelektu i woli, posiada wymiar moralny i zasadza się na moralności dialogujących osób. Charakteryzuje ją szczera chęć podjęcia dialogu w prawdzie i pełnym poszanowaniu współuczestników dialogu.

Dialog w kulturze europejskiej posiada swój paradygmatyczny wzorzec. Są nim Dialogi Platona, którego uważa się za twórcę tego gatunku literackiego, a same Dialogi za tego gatunku „szczytowe osiągnięcie"19. W naszych analizach interesują nas one jako egzemplifikacja dialogu po prostu. Nie tylko posiadają one literacką formę dialogu, lecz wskazują na jego istotne cechy. Dialog platoński, zwłaszcza tzw. sokratyczny, w którym głównym rozmówcą jest Sokrates, podkreśla przede wszystkim niezbywalną rolę żywej rozmowy, której nie zastąpi tekst pisany. Krytyka pisma, jaką znajdujemy w Fajdrosie, jest jednocześnie docenieniem rozmowy i - pośrednio dialogu jako formy życia obywatelskiego, a nie tylko jako teoretycznej dysputy. Krytyka ta zasadza się na prostym spostrzeżeniu, że pismo choć tak jak sztuka malarska sprawia, iż rzeczy stoją przed człowiekiem jak żywe, to przecież gdy się je ktoś zapyta o coś, wtedy uroczyście milczą. Słowa pisane nie wyjaśniają tego, o czym mówią, lecz wciąż tylko powtarzają jedno i to samo ${ }^{20}$. W żywej mowie natomiast rozmówca może wyjaśnić swoje stanowisko, podać argumenty, ale i dostrzec popełnione przez siebie błędy. Dialog jest zatem formą rozmowy, lecz swoistą. Jest raczej debatą na określony temat niż prostą wymianą myśli o różnych sprawach.

18 Por. L. Kuc, Krótki traktat o teologii komunikacji, Wydawnictwo Lumen, Leszno k. Błonia 1997, 25-29.

19 W. Tomaszewska, Metafizyczne i religijne. Problem subtematu w dziele literackim na przykładzie prozy kresowej Włodzimierza Odojewskiego, Wydawnictwo UKSW, Warszawa 2011, 63.

20 Por. Platon, Fajdros, 275d.e, w: Tenże, Dialogi, łłum. z gr. W. Witwicki, Wydawnictwo ANTYK, Kęty 1999. 
Dialogi Platona mają w dużej mierze charakter edukacyjny. Nie tyle chodzi w nich o definitywne rozwiązanie jakiegoś problemu, co o oczyszczenie poglądów rozmówcy z fałszywych mniemań (metoda elenktyczna) i wydobycie wiedzy, którą on posiada (metoda majeutyczna ${ }^{21}$. Dlatego Sokrates niekiedy porzuca rozmówcę przed ostatecznym rozwiązaniem problemu i daje znać, że nie to jest najważniejsze. Ważniejsze od rozwikłania problemu są samokrytycyzm i skromność, jakie winny cechować myśliciela, który nie powinien utrzymywać, że wie coś, czego nie wie ${ }^{22}$. Sokrates poprzez stawiane pytania stara się co prawda podnieść partnera z poziomu przedfilozoficznej niewiedzy i uczynić go równorzędnym partnerem poszukiwania prawdy, lecz przyznaje, że jest to cel odległy, możliwy do osiągnięcia po długim trudzie i tylko wtedy, gdy napotka duszę, zdolną do skorzystania ze wsparcia, jakie daje dialog ustny ${ }^{23}$. Dialog zatem, będąc rozmową osób, cechujących się otwartością na drugiego, nie domaga się od nich równorzędnych kompetencji, gdyż - jak była o tym mowa - nie tyle dąży do rozwikłania jakiegoś problemu, co raczej do uświadomienia sobie przez osoby dialogujące własnej niewiedzy i niewystarczalności w określonej dziedzinie oraz do ubogacenia się przemyśleniami drugiego. Niezależnie od tego, czy będzie dialogiem poznawczym, czy praktycznym, w swej podstawowej warstwie ma charakter intelektualny. Dialog sokratejski, a także wszelki dialog, dotyczy w pierwszym rzędzie mniemań i poglądów na jakiś temat. Na drugim planie, w tle, pozostaje przedmiot, którego

21 Należy przychylić się do twierdzenia, że sokratejska metoda dialogiczna ma zasadniczo cele etyczne i wychowawcze, a dopiero wtórnie i pośrednio logiczne i gnozeologiczne. Por. G. Reale, Historia filozofii starożytnej, t. 1: Od początków do Sokratesa, tłum. z wł. E.I. Zieliński, Redakcja Wydawnictw KUL, Lublin 1993, 370.

22 Por. Platon, Teajtet, 210c, w: Tenże, Dialogi, dz. cyt.

23 Por. Platon, Fajdros 276e-277a, w: Tenże, Dialogi, dz. cyt. Por. T.A. Szlezák, O nowej interpretacji Platońskich Dialogów, tłum. z niem. P. Domański, Wydawnictwo ANTYK, Kęty 2005, 5-24. 
te poglądy dotyczą. Można powiedzieć zatem, że dialog ma temat, lecz nie zawsze ma przedmiot.

Rozmówcy dialogów Platońskich nie są jednakże przypadkowo napotkanymi ludźmi. Ich zgromadzenie jest przemyślane, celowe, choć temat dysput zdaje się pojawiać spontanicznie. Uczta, czyli po grecku Sympozjon, wskazuje na kontekst sytuacyjny debaty o miłości. Jest nim towarzyskie zebranie mężczyzn z greckiej arystokracji, którzy po głównym posiłku przy wspólnym piciu wina, niepozbawionym uciech, debatowali na interesujące ich tematy religijne, społeczne, polityczne czy kulturowe. Choć dialog może brać swój początek od luźnej i niezobowiązującej wymiany myśli z przypadkowo napotkanym rozmówcą, aby zaistniał w pełni, zwłaszcza gdy jest planowany, musi dojść do spotkania między uczestnikami dialogu, a to wymaga nie tylko bezpośredniej obecności, lecz i czegoś więcej. Józef Tischner w kontekście własnej filozofii napisał: „Spotkać to coś więcej niż mieć świadomość, że inny jest obecny obok mnie lub przy mnie. (...) Spotkanie jest wydarzeniem. Spotkanie pociąga za sobą istotną zmianę w przestrzeni obcowań. Ten, kto spotyka, wykracza - transcenduje poza siebie w podwójnym sensie tego słowa: ku temu, komu może dać świadectwo (w stronę innego) i ku temu, przed kim może złożyć świadectwo (przed Nim - tym, kto żąda świadectwa)"24, bo spotkać „znaczy coś więcej i coś innego niż zobaczyć, usłyszeć, podać rękę. (...) Spotkać to osiągnąć bezpośrednią naoczność tragiczności przenikającej wszystkie sposoby bycia Drugiego”25. I jeszcze: „Spotkać znaczy: doświadczać twarzy. Doświadczenie twarzy drugiego odsłania jego prawdę. (...) Do spotkania potrzebna jest (...) wzajemność; doświadczeniu twarzy drugiego musi towarzyszyć odsłonięcie własnej twarzy, drugi musi chcieć przyjąć to, co się odsłoniło. (...)

24 J. Tischner, Filozofia dramatu: wprowadzenie, Éditions du Dialogue, Paris 1990, 27.

25 Tenże, Myślenie według wartości, w: Tenże, Myślenie według wartości, Społeczny Instytut Wydawniczy Znak, Kraków 1982, 487. 
Odsłonięcie prawdy drugiego splata się w spotkaniu ze wzmagającą się świadomością potrzeby ukazania własnej prawdy"26.

Spotkanie jest warunkiem sine qua non dialogu, tak jak rozstanie spotykających się osób jest końcem wszelkich relacji między nimi, a więc i wszelkiego dialogu. Choć spotkanie i dialog to różne fenomeny, przenikają się one wzajemnie na tyle, że niektórzy badacze filozofię spotkania utożsamiają z filozofią dialogu ${ }^{27}$. Gdy Martin Buber uzna, że „(...) każde prawdziwe życie jest spotkaniem”28, Emmanuel Lévinas będzie wskazywał, że dialog, jaki nawiązuje się między mną a Drugim (Innym), daruje mi świat, gdyż to właśnie słowo, zakładające obecność Drugiego, pokazuje mi rzeczy, wydobywa ich osobliwość, ich sens z anarchii danych, ale przede wszystkim odsłania przede mną mnie samego ${ }^{29}$. Adam Węgrzecki rozróżnia spotkanie i dialog. Spotkanie ujmuje jako proces kontaktowania się z drugim człowiekiem, „w którym zostaje zawiązana i rozwinięta osobowa relacja Ja - Ty, wolna od uprzedmiotowienia drugiego i od jakichkolwiek redukcjonistycznych ograniczeń jego bytu", a który to proces ,pozostawałby realny, bezpośredni, autentyczny i przynajmniej niekiedy znaczący”30. „W spotkaniu - pisze Węgrzecki - możliwie pełnym i autentycznym dialog nie tylko może wystąpić, ale wręcz trudno sobie wyobrazić, żeby do niego nie doszło. Gdyby go zabrakło, można by nawet uznać, że spotkanie nie rozwinęło się w pełni, że

26 J. Tischner, Bezdroża spotkań, Analecta Cracoviensia 12(1980), 137.

27 A. Węgrzecki do badaczy, zajmujących takie stanowisko, zalicza M. Theunissena, J. Madera, B. Barana, K. Święcicką, T. Gadacza. Por. A. Węgrzecki, Wokół filozofii spotkania, Wydawnictwo WAM, Kraków 2014, 19.

28 M. Buber, Ja i Ty. Wybór pism filozoficznych, tłum. z niem. J. Doktór, PAX, Warszawa 1992, 45.

29 Por. E. Lévinas, Całość i nieskończoność. Esej o zewnętrzności, tłum. z fr. M. Kowalska, Wydawnictwo Naukowe PWN, Warszawa 1998; por. M. Jędraszewski, Wobec Innego. Relacje międzypodmiotowe w filozofii Emmanuela Lévinasa, Księgarnia Św. Wojciecha, Poznań 1990.

30 A. Węgrzecki, Wokół filozofii spotkania, dz. cyt., 90-91. 
nie nastąpiła w nim wzajemna prezentacja siebie przez uczestników spotkania" 31.

Przedstawiciele filozofii spotkania czy filozofii dialogu upatrują w spotkaniu i dialogu źródłowy, autentyczny sposób bytowania człowieka w świecie, w którym miejsce szczególne zajmuje Inny. Filozofowie ci uznali spotkanie i dialogiczność za ontyczny fundament bytowania osoby, co się dostrzega, nie identyfikując się z wymienionymi tu nurtami filozoficznymi. Człowiek bowiem jest bytem społecznym, tzn. pozostającym $\mathrm{w}$ rozlicznych relacjach $\mathrm{z}$ innymi ludźmi, aktualizującym swoje potencjalności, także potencjalności umysłowe, który jako byt mówiący (homo loquens), posługujący się mową artykułowaną, nie tyle informuje drugiego o treściach swoich przeżyć świadomych, lecz konstytuuje wspólnotę osób w dialogu właśnie. Dopiero bowiem dialog sprawia, że wspólnota osób urzeczywistnia się, stając się z Ja i Ty swoistym My, czego nie zapewnia żadna przygodna rozmowa.

Dialog należy zatem uznać za fundament życia społecznego, zgodnego z naturą człowieka. Może ono być bowiem w pełni ludzkim życiem społecznym tylko wtedy, gdy osoby otworzą się na siebie, udzielając drugim i dzieląc się z nimi tym, co naprawdę ich własne: swoją myślą. Byty w pełni izolowane, zamknięte w sobie, nie mogą tworzyć społeczności. Mogą to czynić - jak o tym była mowa - jedynie te byty, które są zdolne do komunikowania innym własnych treści świadomości, czyli do rozmowy, oraz które są zdolne do przyjęcia komunikatów od innych, afirmując ich równocześnie jako pełnoprawnych uczestników dialogu, a właściwie - jego współsprawców. Tomasz z Akwinu w communicatio, będącej do pewnego stopnia odpowiednikiem greckiej diálogos, dostrzegał konieczny warunek

31 Tamże, 20. Trudno byłoby mi się zgodzić z Węgrzeckim, że dialog może występować poza spotkaniem w przyjętym przez niego sensie, chyba że dialog zostanie zredukowany do rozmowy. 
miłości jako cnoty społecznej. Miłować można bowiem jedynie tego, kto komunikuje się z człowiekiem w życiu rozumnym ${ }^{32}$.

Dialogiczność, mająca swe ugruntowanie w ontyce bytu ludzkiego, może i winna stać się świadomie przyjmowaną postawą, postawą otwartości na drugiego, która pozwala mu mówić o sobie i o świecie oraz o swoim widzeniu świata, a także - nakazuje drugiego wysłuchać. Drugiego należy afirmować jako osobę wraz z jego poglądami, co nie jest równoznaczne $\mathrm{z}$ akceptacją tych poglądów. Wprost przeciwnie: afirmacja drugiego jako osoby domaga się od afirmującego krytycznego (w sensie źródłowym) ustosunkowania się do jego poglądów, by błędne poprawić, a słuszne wzmocnić. Można powiedzieć, że jest to imperatyw, zakorzeniony w naturze osoby. Człowiek, pragnący bytować w zgodzie $\mathrm{z}$ samym sobą, tzn. $\mathrm{z}$ własną ontyką, winien tę cechę własnego bytu wydobyć na jaw, na poziom świadomie przyjmowanej postawy, będącej jego habitualnością, tak jak świadomie uznaje się za poznającego i wolnego, nawet gdy aktualnie nie spełnia żadnych aktów poznawczych czy wolitywnych. Postawa dialogiczna jest bowiem warunkiem faktycznie prowadzonego dialogu, zarówno w płaszczyźnie teoretycznej (poznawczej), jak i praktycznej (sprawczej: moralnej lub wytwórczej). Co więcej: inaczej niż w mówieniu i rozmowie, w których pierwszorzędnie ujawnia się sama czynność mówienia lub rozmawiania, w dialogu tym, co konstytuujące, jest przede wszystkim postawa dialogiczna czy nastawienie podmiotu dialogu, pożądane w życiu społecznym, a zakorzenione w ludzkiej naturze. Od owej postawy czy nastawienia, zwanych dialogicznością, trzeba odróżnić dialog jako ich urzeczywistnienie, przejawiające się przede wszystkim w kwalifikowanej rozmowie. W dialogu, czyli $\mathrm{w}$ urzeczywistnianiu owej postawy czy nastawienia, ważniejsza od

32 Por. Thomas Aquinatis, Summa theologie, II-II, q. 25, a. 3, sc., red. Marietti, t. 1-4, Taurini-Romae 1962-1963 - Suma teologiczna, tłum. z łac. i red. S. Bełch, t. 1-35, Katolicki Ośrodek Wydawniczy „Veritas”, London 1962-1998. 
wyznaczonego (często mgliście) celu jest droga ku niemu, którą zmierzają dialogizujący na określony temat.

\section{DYSKUSJA}

Popularność dialogu, który się uprawia i prowadzi, którego się oczekuje i dostrzega się w nim remedium na liczne bolączki współczesności, usunęła w cień dyskusję, w której można dopatrywać się osobliwej odmiany dialogu. Momenty, różnicujące dyskusję od dialogu, uwidaczniają się już w znaczeniu terminu. Łacińska discussio wywodzi się od czasownika discutere, który przyjmuje m.in. następujące znaczenia: badać, rozpatrywać, roztrząsać, rozsądzić, wyjaśnić, wyłożyćc ${ }^{33}$. Dyskusja nie jest zatem wymianą sądów lub opinii jak w dialogu, a tym bardziej - jak w zwyczajnej rozmowie, lecz wyraźnym ich zderzeniem w celu ich merytorycznego rozważenia, skorygowania, uzgodnienia lub odrzucenia w obliczu określonego przedmiotu ${ }^{34}$. Można powiedzieć, że dyskusja jest dialogiem kwalifikowanym, tak jak dialog jest kwalifikowaną rozmową.

Roman Ingarden w krótkim, lecz znaczącym artykule $O$ dyskusji owocnej stów kilka ${ }^{35}$ podaje kilka warunków, jakie winny być spełnione, by dyskusja rzeczywiście była owocna. Niektóre z nich dotyczą także dialogu, inne są specyficzne dla dyskusji. Mając na uwadze przede wszystkim dyskusję, Ingarden wskazuje, że motywem jej podjęcia jest ograniczoność i ułomność sił twórczych poszczególnego człowieka, a w szczególności jego sił poznawczych. Ale już świadomość własnej jednostronności i stronniczości, będącej następstwem uzdolnień i sprawności konkretnego człowieka, a także jego upodobań, motywuje nie tylko dyskusję, lecz także wszelki dialog. Natomiast chęć przeforsowania własnego stanowiska w jakiejkolwiek

33 Słownik łacińsko-polski, dz. cyt., t. 2, Warszawa 1962, 192.

34 Por. W. Marciszewski, Sztuka dyskutowania, Wydawnictwo Iskry, Warszawa 1996, 4.

35 R. Ingarden, Książeczka o człowieku, Wydawnictwo Literackie, Kraków 1972, 185-190. 
sprawie z góry uniemożliwia rzetelny dialog czy dyskusję. Dlatego koniecznym warunkiem owocnego dialogu i owocnej dyskusji jest ich swoboda formalna, przejawiająca się w braku jakichkolwiek zewnętrznych ograniczeń, oraz wewnętrzna swoboda dyskutantów, na której Ingarden się skupia. Rodzi się ona z absolutnej rzetelności myślenia, ze szczerości wobec siebie samego oraz z nieustraszonego dążenia do wyjaśnienia spraw niewyjaśnionych i skontrolowania przyjmowanych twierdzeń czy żywionych przeświadczeń. Cechować ją powinna wszechstronność, tzn. winna ona dotyczyć nie tylko cudzych, lecz i własnych twierdzeń, przywiązań do pewnych idei, wartości i umiłowań. Wszechstronna swoboda wewnętrzna przejawia się w gotowości: (1) zawieszenia własnej oceny cudzego stanowiska czy postawy; (2) rzetelnego zapoznania się z cudzym stanowiskiem niejako w oryginale; oraz (3) uznania cudzego poglądu, jeśli ten okaże się zasadny. Łączy się z tym gotowość odstąpienia od własnych przyzwyczajeń intelektualnych i własnej aparatury pojęciowej.

Ingarden powie także, że dyskusja, co nie jest konieczne dla dialogu, domaga się od biorących w nim udział „woli współpracy - na równych prawach i przy równym wysiłku i równej rzetelności”36. Inaczej niż w szeroko rozumianej rozmowie i w dialogu, dyskusja służy bowiem rozwiązaniu jakiegoś konkretnego (teoretycznego lub praktycznego) problemu. Jej celem jest dojście z teoretycznym przeciwnikiem do prawdy - i dodajmy - do tego, co słuszne, sprawiedliwe czy pożyteczne. W istocie dyskusja ma zawsze charakter poznawczy, nawet jeśli jej rezultaty będą miały znaczenie praktyczne. A zatem w dyskusji, inaczej niż w dialogu, liczą się przede wszystkim merytoryczne kompetencje dyskutantów, będące warunkiem ich owocnej współpracy. W dyskusji na pierwszy plan wysuwają się argumenty rzeczowe, a sami dyskutanci pozostają $\mathrm{w}$ ich cieniu.

Powyższe uwagi Ingardena dotyczą przede wszystkim podmiotowych warunków dyskusji. Trzeba je uzupełnić o warunki formalne, 
jakie winny być spełnione, by była ona rzeczywiście owocna. Sprawą zasadniczą jest wyraźne określenie zagadnienia, którego rozwiązanie jest celem dyskusji, z czym wiąże się wskazanie przedmiotu i aspektu dyskusji, a także uzgodnienie pojęć, jakimi dyskutanci będą się posługiwali. Dyskusja może dotyczyć rzeczy (dyskusja przedmiotowa) lub naszej wiedzy o rzeczy (dyskusja metaprzedmiotowa). Choć przedmiotem dyskusji może być cokolwiek, nie o wszystkim warto dyskutować. Nie warto dyskutować ani o rzeczach oczywistych - te nie są żadnym problemem, ani o sprawach banalnych, mało interesujących z określonego punktu widzenia.

Tadeusz Czeżowski również w krótkim artykule $O$ dyskusji i dyskutowaniu ${ }^{37}$ zdaje się pojmować dyskusję dość szeroko jako wymianę myśli, jednakże faktycznie ogranicza ją do takiej jej wymiany, która jest „prowadzona w pewnym porządku i zmierza do określonego celu intelektualnego (poznawczego) lub praktycznego"38, co pozwala mu wyróżnić dyskusje teoretyczne i praktyczne. Koncentrując się na dyskusjach o charakterze naukowym, Czeżowski zwraca uwagę na konieczność uzasadnienia przywoływanych twierdzeń oraz na wewnętrzną logikę dyskusji, wyznaczoną przez podjęte zagadnienie (wymagania naukowe), a także na jej organizację, gdy w dyskusji bierze udział więcej osób (wymagania parlamentarne). Niezależnie od tego, jaki dyskusja ma przebieg, ,trzeba pamiętać zawsze o tym pisze Czeżowski - że aby była ona rzeczowa, chodzić w niej powinno o uzasadnienie twierdzeń i wykazanie ich prawdziwości lub prawdopodobieństwa, nie zaś o przekonanie przeciwnika i przeciągnięcie go na swoją stronę"39.

Momentem wyróżniającym dyskusję jest argumentacja, która zawsze winna być rzeczowa, tzn. mająca swe uzasadnienie w samej

37 Por. T. Czeżowski, O dyskusji i dyskutowaniu, w: Tenże, Odczyty filozoficzne, Wydawnictwo Towarzystwa Naukowego w Toruniu, Toruń 19692, 191-196.

38 Tamże, 191.

39 Tamże, 194. 
badanej rzeczy, lub czysto formalna, tzn. dotycząca samego sposobu argumentowania czy formy wnioskowania. W dialogu, w którym nie chodzi o rozwiązanie jakiegoś problemu, lecz o zdanie sobie sprawy z poglądów żywionych przez drugich, argumentacja nie odgrywa pierwszorzędnej roli. Z rzetelnej dyskusji, ale i z dialogu, którego celem nie jest przeciągnięcie partnera na swoją stronę, trzeba zatem wyeliminować chwyty erystyczne, które są podporząadkowane zwycięstwu w dyskusji, a nie rozwiązaniu problemu. Chwyty te, których katalog zestawił Arthur Schopenhauer w swej Erystyce czyli sztuce prowadzenia sporów ${ }^{40}$, nie tylko są wadliwe logicznie, lecz także i przede wszystkim - świadomie stosowane są niegodziwe moralnie.

Witold Marciszewski z kolei przedstawia m.in. schemat przebiegu owocnej dyskusji. Wyróżnia w niej cztery zasadnicze fazy. Pierwsza faza to kształtowanie problemu. Służy ona wyraźnemu określeniu tego, co wiemy, i tego, czego nie wiemy, a czego chcielibyśmy się dzięki dyskusji dowiedzieć. Problem zazwyczaj formułuje się w postaci pytań, które winny spełniać warunki poprawności, trafności i zasadności. Fazą drugą jest szukanie pomysłów rozwiązania problemu i formułowanie wielu konkurencyjnych hipotez. Trzecia fazą dyskusji i jej rdzeniem jest krytyka zgłoszonych pomysłów rozwiązania problemu celem wyeliminowania tych, które nie rokują, że doprowadzą do merytorycznych rozwiązań. W czwartej fazie komunikuje się wnioski oraz przedstawia argumenty, przemawiające za przyjętymi wnioskami ${ }^{41}$. Osiągnięte wnioski mogą być zaczynem nowej dyskusji, zarówno podejmującej dalsze zagadnienia, jakie się wyłaniają, jak i weryfikującej poczynione ustalenia.

Jednakże trzeba zawsze pamiętać, że nie zawsze rację ma zwycięzca w jakimkolwiek sporze, także w dyskusji. Każda dyskusja

40 A. Schopenhauer, Erystyka czyli sztuka prowadzenia sporów, tłum. z niem. B. i L. Konorscy, Wydawnictwo Literackie, Kraków 1973.

41 Por. W. Marciszewski, Sztuka dyskutowania, dz. cyt., 34-43, 146-154. Por. M. Mieszczakowski, Zagadnienie dyskusji w pismach Witolda Marciszewskiego, Warszawa 2001, msp. 
jest bowiem ograniczona czasowo, gdy dialog, niebędący dyskusją, może być czasowo niezamknięty. Nie zawsze tak jest, że w trakcie dyskusji jej uczestnicy posiadają pod ręką wszystkie merytoryczne argumenty za bronioną tezą czy stanowiskiem, że wszyscy są równie biegli w formułowaniu myśli i wysnuwaniu wniosków. Często się zdarza, że najważniejsze argumenty przychodzą dyskutantom do głowy już po zakończeniu dyskusji. Nadto - postęp w głębszym poznaniu rzeczy i rozumieniu problemu, również dzięki ukończonej dyskusji, przywodzi nowe argumenty, które dotychczas nie zostały przywołane. A jest tak, gdyż - jak zauważa Czeżowski - każda, zwłaszcza ustna, dyskusja ,jest do pewnego stopnia improwizacją. Przygotowany bywa tylko punkt wyjścia dyskusji w postaci referatu, który wprowadza w jej przedmiot. (...) Los szczęścia decyduje w znacznej mierze o tym, czy dyskusja należycie się rozwinie"42.

\section{PODSUMOWANIE}

Mówienie, rozmowa, dialog i dyskusja to nie tylko cztery bliskoznaczne terminy, lecz i cztery fenomeny ze sobą spokrewnione i na siebie nachodzące. Mówienie jako sensowne artykułowanie dźwięków przez podmiot osobowy, będąc warunkiem pozostałych, nie wymaga osobowego adresata, a nawet biernego słuchacza. Mówienie może być monosubiektywne, niemniej zawsze jest niekoniecznym mówieniem określonych treści, ukształtowanych przez podmiot. Pierwszorzędnym i wystarczającym celem mówienia może być ono samo, czyli po prostu mówienie, choć najczęściej dookreślane jest przez inne cele, dla osiągnięcia których mówienie jest środkiem. Rozmowa jest wzajemnym mówieniem do siebie przynajmniej dwóch osób, choćby przypadkowo napotkanych, na jakiś niekoniecznie sprecyzowany temat. Wystarczającym warunkiem jest, by uczestnicy rozmowy byli zdolni do mówienia i słuchania oraz zechcieli przekazać

42 T. Czeżowski, O dyskusji i dyskutowaniu, dz. cyt., 194. 
rozmówcy określone treści w zrozumiałym dlań języku. Szczególnym przypadkiem rozmowy jest rozmowa $z$ samym sobą. Podobnie jak ma się sprawa z mówieniem, pierwszorzędnym i wystarczającym celem rozmowy jest ona sama, choć najczęściej służy ona jeszcze innym celom, co wymaga przyjęcia przez rozmówców odpowiedniej postawy czy nastawienia. Dialog i dyskusja to kwalifikowane rozmowy osób, które winny się cechować wewnętrzną wolnością, pozwalającą odstąpić od żywionych przez siebie przeświadczeń. Ani na miano dialogu, ani na miano dyskusji nie zasługują takie spory słowne, kłótnie, których celem jest „postawić na swoim”, często za wszelką cenę, a więc także za cenę prawdy, słuszności czy poprawności wywodu ${ }^{43}$. Głównym celem dialogu jest zapoznanie się ze stanowiskiem i poglądami jego uczestników na określony temat, a także - a może przede wszystkim - zbudowanie płaszczyzny porozumienia miedzy uczestnikami dialogu, którzy nie muszą posiadać równych kompetencji. W dialogu, bardziej niż w rozmowie i w dyskusji, uwidaczniają się: właściwe nastawienie i postawa dialogujących osób, które gwarantują jego owocność, nawet jeśli teoretyczne lub praktyczne cele określonego dialogu nie zostaną osiągnięte. Dlatego dialog domaga się spotkania i spojrzenia sobie w twarz przez dialogujących, dlatego dialog głęboko sięga ontyki osoby. Dyskusję można uznać za dialog sformalizowany, kwalifikowany. Jej celem jest rozwiązanie jakiegoś problemu. W dyskusji musi być zatem wyraźnie określony jej przedmiot, aspekt oraz muszą zostać uzgodnione pojęcia, a dyskutanci muszą posiadać podobne kompetencje w dyskutowanych sprawach. Dyskusja posiada też swą wewnętrzną, logiczną strukturę, jeśli ma być owocna.

Poczynione tu rozróżnienia między mówieniem, rozmową, dialogiem i dyskusją nie są arbitralne. Ukazują istotne różnice, ale i podobieństwa. Mówienie, rozmowa, dialog i dyskusja są bowiem

43 Por. T. Kotarbiński, Przedmowa, w: A. Schopenhauer, Erystyka czyli sztuka prowadzenia sporów, dz. cyt., 6. 
spokrewnionymi ze sobą aktywnościami człowieka, nie zawsze odróżnianymi, bo często przechodzącymi jedne w drugie, a w mowie nie tylko potocznej nazywanymi tymi samymi słowami. Niemniej pewne uporządkowanie tych aktywności i dostrzeżenie różnic w podobnych do siebie fenomenach może być pomocne w świadomym ich urzeczywistnianiu.

\section{BIBLIOGRAFIA}

Arystoteles, Retoryka, tłum. z gr. H. Podbielski, w: Tenże, Dzieła wszystkie, t. 6, Wydawnictwo Naukowe PWN, Warszawa 2001, 265-478.

Augustyn, O nauczycielu, tłum. z łac. J. Modrzejewski, w: Tenże, Dialogi filozoficzne, Wydawnictwo Znak, Kraków 1999, 421-485.

Benveniste E., Struktura języka i struktura spoteczeństwa, tłum. z fr. K. Falicka, w: Jezzyk i spoteczeństwo, red. M. Głowiński, Czytelnik, Warszawa 1980, 27-40. Buber M., Ja i Ty. Wybór pism filozoficznych, tłum. z niem. J. Doktór, PAX, Warszawa 1992.

Czeżowski T., O dyskusji i dyskutowaniu, w: Tenże, Odczyty filozoficzne, Wydawnictwo Towarzystwa Naukowego w Toruniu, Torun 1969², 191-196.

Grzegorczyk A., O języku ludzkim jako istotnej cesze cztowieka, w: Swoistośćcztowieka? Jezyk, red. J. Tomczyk, G. Bugajak, Wydawnictwo UKSW, Warszawa 2008, 47-66.

Gut A., O relacji między myśla a językiem, Towarzystwo Naukowe KUL, Lublin 2009.

Husserl E., Idee czystej fenomenologii ifenomenologicznej flozofii. Ksiega druga, thum. z niem. D. Gierulanka, PWN, Warszawa 1974.

Ingarden R., O dyskusji owocnej stów kilka, w: Tenże, Ksiq̨̇̇eczka o cztowieku, Wydawnictwo Literackie, Kraków 1972, 185-190.

Jędraszewski M., Wobec Innego. Relacje międzypodmiotowe w filozofii Emmanuela Lévinasa, Księgarnia Św. Wojciecha, Poznań 1990.

Kleszczowa K., O wyrazie „rozmowa” słów kilka, w: Porozmawiajmy o rozmowie. Lingwistyczne aspekty dialogu, red. M. Kita, J. Grzenia, Wydawnictwo Uniwersytetu Śląskiego, Katowice 2003, 11-15.

Korolko M., Sztuka retoryki. Przewodnik encyklopedyczny, Wiedza Powszechna, Warszawa 1990. 
Kotarbiński T., Przedmowa, w: A. Schopenhauer, Erystyka czyli sztuka prowadzenia sporów, tłum. z niem. B. i L. Konorscy, Wydawnictwo Literackie, Kraków 1973, 5-7.

Krokos J., Dialog i dyskusja, Zarządzanie i Edukacja (2010)68-69, 235-244.

Kuc L., Krótki traktat o teologii komunikacji, Wydawnictwo Lumen, Leszno k. Błonia 1997.

Lévinas E., Catość i nieskończoność. Esej o zerwnętrzności, tłum. z fr. M. Kowalska, Wydawnictwo Naukowe PWN, Warszawa 1998.

Marciszewski W., Sztuka dyskutowania, Wydawnictwo Iskry, Warszawa 1996.

Mieszczakowski M., Zagadnienie dyskusji w pismach Witolda Marciszerwskiego, Warszawa 2001, msp.

Platon, Dialogi, tłum. z gr. W. Witwicki, t. 1-2, Wydawnictwo ANTYK, Kęty 1999.

Reale G., Historia filozofii starożytnej, t. 1: Od początków do Sokratesa, tłum. z w1. E.I. Zieliński, Redakcja Wydawnictw KUL, Lublin 1993.

Saussure F. de, Kurs językoznawstwa ogólnego, tłum. z fr. K. Kasprzyk, PWN, Warszawa $1991^{2}$.

Schopenhauer A., Erystyka czyli sztuka prowadzenia sporów, tłum. z niem. B. i L. Konorscy, Wydawnictwo Literackie, Kraków 1973.

Stownik grecko-polski, red. Z. Abramowiczówna, t. 1-4, PWN, Warszawa 1958-1965. Stownik języka polskiego PWN, https://sjp.pwn.pl, [dostęp 12.9.2020].

Stownikjęzyka polskiego, red. M. Szymczak, t. 1-3, Wydawnictwo Naukowe PWN, Warszawa 1978-1981.

Stownik tacińsko-polski, red. M. Plezia, t. 1-5, PWN, Warszawa 1959-1979.

Szlezák T.A., O nowej interpretacji Platońskich Dialogórw, tłum. z niem. P. Domański, Wydawnictwo ANTYK, Kęty 2005.

Thomas Aquinatis, Summa theologie, red. Marietti, t. 1-4, Taurini-Romae 1962-1963 - Suma teologiczna, tłum. z łac. i red. S. Bełch, t. 1-35, Katolicki Ośrodek Wydawniczy „Veritas”, London 1962-1998.

Tischner J., Bezdroża spotkań, Analecta Cracoviensia 12(1980), 137-172.

Tischner J., Filozofia dramatu. Wprowadzenie, Éditions du Dialogue, Paris 1990. Tischner J., Myślenie wedtug wartości, w: Tenże, Myślenie wedtug wartości, Społeczny Instytut Wydawniczy Znak, Kraków 1982, 481-497.

Tomaszewska W., Metafizyczne i religijne. Problem subtematu w dziele literackim na przyktadzie prozy kresowej Wtodzimierza Odojewskiego, Wydawnictwo UKSW, Warszawa 2011. 
Tomczyk J., W poszukiwaniu korzeni mowy artykutowanej, w: Swoistośćcztowieka? Język, red. J. Tomczyk, G. Bugajak, Wydawnictwo UKSW, Warszawa 2008, 67-93.

Węgrzecki A., Wokót filozofii spotkania, Wydawnictwo WAM, Kraków 2014. Wielki stownik języka polskiego, https://wsjp.pl, [dostęp 12.9.2020].

Żychliński A., Homo loquens. O różnicy antropologicznej, Teksty Drugie (2009)5, 56-84.

\section{SPEAKING - CONVERSATION - DIALOGUE - DISCUSSION}

Abstract. Speaking, conversation, dialogue and discussion are four synonymous terms and refer to four related phenomena. Speaking is a sensible articulation of sounds by a personal subject, and as such is a condition for other activities. Conversation occurs when at least two people talk to each other on a topic. Dialogue and discussion, which are a form of conversation between persons, are characterized by different objects, purpose and structure. In both cases, conversation is foundational. The main condition of dialogue and discussion consists in the freedom of the will of persons. The main purpose of dialogue is the recognition of the views of participants. The participants in a discussion must not own equal competence. Discussion is a formalized dialogue. Thus, the purpose of a discussion is to solve problems. Therefore, there must be a definite object in discussion, and the details and notions employed must be stated. Moreover, the participants in discussion must own a similar competence. Lastly, discussion possesses its own internal and logical structure.

Keywords: speaking; conversation; dialogue; discussion

\footnotetext{
Jan Krokos

Uniwersytet Kardynała Stefana Wyszyńskiego w Warszawie, Instytut Filozofii (Cardinal Stefan Wyszyński University in Warsaw, Institute of Philosophy, Poland)

ORCID: https://orcid.org/0000-0002-5184-5922

j.krokos@uksw.edu.pl

DOI: 10.21697/spch.2020.56.4.15
} 